\title{
BALIKA fact sheet: Highlight on marriage
}

Population Council

Follow this and additional works at: https://knowledgecommons.popcouncil.org/departments_sbsr-pgy

Part of the Demography, Population, and Ecology Commons, Family, Life Course, and Society Commons, International Public Health Commons, and the Women's Health Commons How does access to this work benefit you? Let us know!

\section{Recommended Citation}

"BALIKA fact sheet: Highlight on marriage." New York: Population Council, 2014. 


\section{Early marriage deprives girls of the opportunity for personal development and their rights to full reproductive health and well-being, education, and participation in civic life.}

- Bangladesh stands out in international comparisons as having an extraordinarily early age at marriage for girls and a considerable average age difference in marriage between girls and their husbands.

- Previous research suggests marriage usually puts an end to schooling. Entry into marriage usually means taking on significant responsibilities in the marital home and thus an abrupt change in their roles for which these young girls are not psychologically or physically prepared.

- Prior research also shows that many have no choice about the timing of marriage or their partner. Some are coerced into marriage, while others are too young to make an informed decision.

- The Child Marriage Restraint Act of 1929 of colonial South Asia specified 15 years as the legal minimum age at marriage for girls. The laws have been reformed in multiple ways in present day Bangladesh and specify that the legal minimum age of marriage is 18 for girls and 21 for boys.

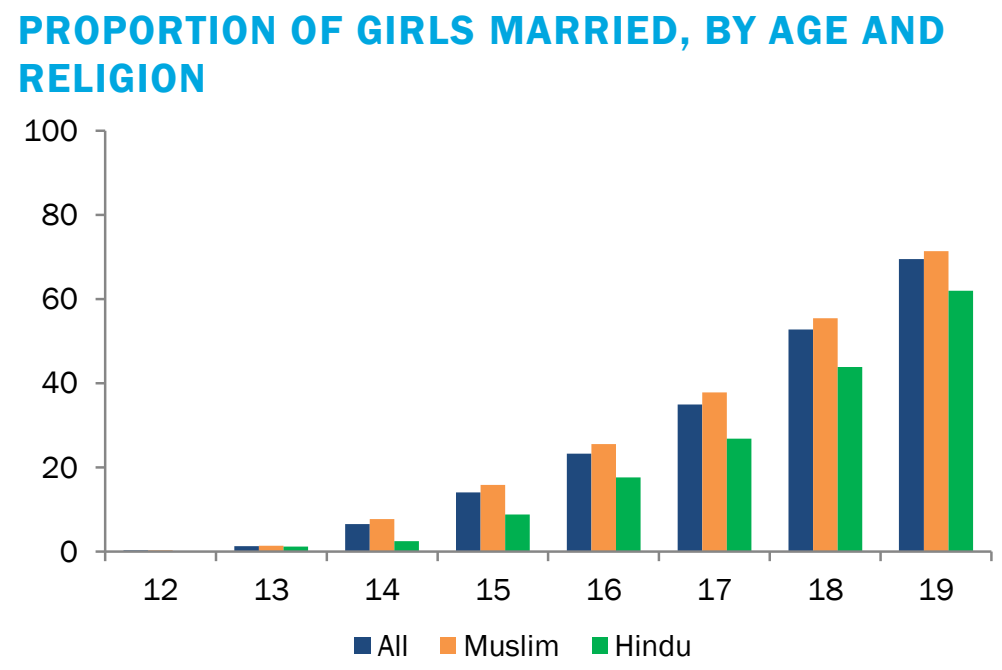

\section{HIGHLIGHTS}

- Despite many legal provisions to discourage child marriage, girls continue to be married at very young ages in Bangladesh.

- The practice of dowry (payments made by a bride and her family to the groom and his family) is still persistent. For Hindus, the custom of dowry payment is a longstanding tradition, whereas for Muslims it is a relatively new practice. Twenty-eight percent of marriages in the study districts involve a dowry transaction. Dowry amounts increase with a girl's age at marriage. A girl's marriageability is thought to be associated with her beauty; dowry amounts are often less for beautiful girls.

- "Own choice" or "love marriages" (marriages where the choice of marriage partner is made by the partners themselves) are on the rise: $\mathbf{2 3}$ percent of marriages are characterized as love marriages and are more common among girls with more education. They are also less likely to involve a dowry.

- Over 90 percent of underage marriages are registered by obtaining false birth certificates.

The Population Council conducts research and delivers solutions that improve lives around the world. Big ideas supported by evidence: It's our model for global change. popcouncil.org 
- Marriage rates increase rapidly after age 14---at age 15 about one in six girls is married, at age 16 one in four is married, at age 17 one in three, at age 18 one in two and by 19 two out of three girls are married.

- Religious differences in early marriage rates are small but Muslims are consistently more likely to marry early compared to Hindus.

A GIRL'S BEAUTY IS THOUGHT TO BE ASSOCIATED WITH HER AGE AND MARRIAGEABILITY

"When girls are at the age of 16 or below, they are more beautiful; after that their beauty starts to drop and who will want to take her then?"

\section{-MALE RESPONDENT}

\section{DOWRY IN MARRIAGE}

- $28 \%$ of girls are married with dowry.

THE AMOUNT OF DOWRY PAID INCREASES WITH AGE AT MARRIAGE.

"18 is a critical age. If a girl is older than 18, men think she is very old-in our local dialect we say 'she has ripened.' The groom's family makes more demands on the bride's family for dowry saying who will agree to marry your daughter now at her age."

-BOYS' FOCUS GROUP DISCUSSION

BEAUTIFUL GIRLS ARE EXEMPTED FROM DOWRY PAYMENT

"If a girl is beautiful, dowry is not required. The boys are ready to take her without a single penny, and may even give her jewelry and other things that are required in marriage"

-BOYS' FOCUS GROUP DISCUSSION

\section{CHOICE IN MARRIAGE}

- $23 \%$ of marriages are "own choice" or love marriages.

- Own choice marriages are found more frequently among girls who have secondary or higher education.

- The percentage of marriages involving dowry is lower in love marriages.

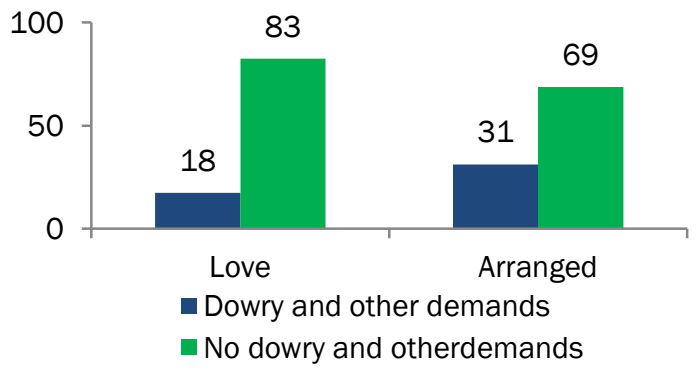

POVERTY AND INSECURITY OF GIRLS IN SOCIETY ARE STATED AS MAJOR REASONS FOR GIRLS' YOUNGER AGE AT MARRIAGE

“...there was shortage of food; it was not possible for my father to meet the demands of the family. That's why he thought to marry me off, to lessen the burden, thinking that at least the other children would then be provided for then."

-GIRL, 19 YEARS OLD, MARRIED AT AGE 12

\section{MARRIAGE REGISTRATION}

As early as the marriage may be, most underage marriages (92\%) are registered.

"Underage marriage is not a problem here when both the bride's and groom's family have agreed to it. They produce false birth certificate from the Union Council. The Kazi (marriage registrar) sees that there is a certificate, so legally he can register the marriage... It is only a matter of TK 50 (less than \$US 1) to make a birth certificate."

-BOYS' FOCUS GROUP DISCUSSION

\section{KNOWLEDGE ABOUT MARRIAGE LAW AND THE RIGHT TO DIVORCE}

Both married and unmarried adolescents are more likely to know about underage marriage than about their rights to divorce. About two-thirds of adolescents know the specific punishments under the law for underage marriage but only one in three girls know that women have the right to divorce.

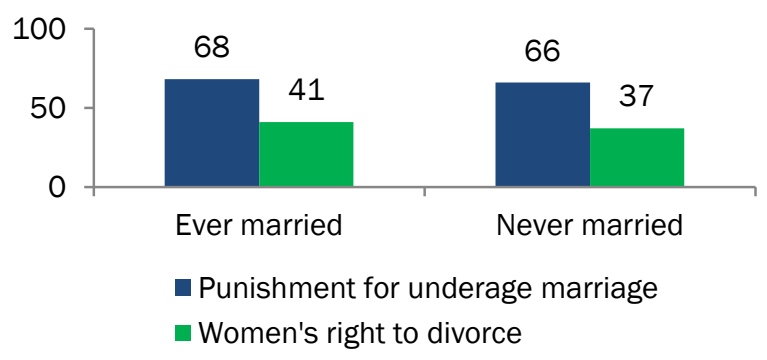

\section{CONCLUSION}

Marriage remains early by most standards and the majority of girls still get married before reaching the legal age of 18 years. By age 19 more than two-thirds of girls are married.

Dowry amounts increase with age at marriage. Both young age at marriage and physical beauty are valued attributes and require a smaller dowry. The proportion of marriages that are "love" or "own choice" is highest among girls with the most education. These marriages are less likely to involve a dowry payment. Even though marriage under age 18 is illegal in the Bangladesh, there is general social acceptance of marrying girls at an early age. Most such marriages are registered by fabricating birth certificates. 